\title{
0 uso de animais em pesquisas científicas
}

Lanfranco Ranieri Paolo Troncone

$\mathrm{N}$ os países onde a ciência recebe tratamento prioritário esta discussão já se esgotou. O emprego de animais em experimentação pode ser avaliado por vários ângulos. Um artigo abrangente sobre os aspectos técnicos e históricos desta questão foi publicado na edição de número 144, de fevereiro de 2008, da Revista Pesquisa Fapesp. Após a leitura desta matéria muitos concordarão que a discussão desse polêmico assunto já é coisa do passado. Para não deixar uma lacuna neste texto, só consigo acrescentar que não há nenhuma maneira de substituir um organismo vivo quando se trata de fazer ciência no campo da psicologia e do comportamento. Seres vivos se comportam. Até mesmo paramécios e amebas se comportam, aprendem e respondem a estímulos. Nisso o ser humano se parece com um unicelulado. Modelos animais de distúrbios psíquicos são largamente usados em todo o mundo e não há como substituí-los por modelos in vitro, como gostariam os críticos do uso de animais em experimentação. Talvez este tipo de investigação seja o que mais provoca as paixões, pois a incompreensão dos processos psíquicos humanos e a relutância em atribuir caracteres humanos a animais, que se chama de antropomorfisação, dificulta a avaliação fria dos fatos. Se uma pessoa pode ser levada à depressão ou à ansiedade, seja por um desequilíbrio neuroquímico (endógeno) ou por uma situação vivencial (reativa), é porque uma doença existe ou porque uma situação se impôs à pessoa e a levou ao desequilíbrio. Enquanto as bases fisiopatológicas desses distúrbios (e de todos os outros) não forem completamente conhecidas, não haverá maneira de substituir os modelos animais. Portanto, um dia a ciência conseguirá ter estas respostas apenas, e tão somente, se empregar modelos animais agora e ainda por muito tempo. Creio que uma questão ética como esta merece uma reflexão de caráter filosófico.

A pergunta que se pretende responder é simples e direta: Nós temos o direito de usar animais para investigação científica? Se a resposta for sim a questão estará esgotada, mas se a resposta for não somos levados a refazer a pergunta com uma abrangência maior: Nós temos o direito de usar animais? Isso pode parecer uma regressão inútil mas evidencia um vício de raciocínio por parte daqueles que se opõem à experimentação animal. O vício está em achar que o que se faz com animais em laboratório é cruel, desnecessário e/ou dá prazer ao experimentador. Não há nada mais errado do que esta idéia. Nunca conheci em toda minha vida, ninguém que tivesse prazer em usar animais em seus experimentos na ciência (quase 30 anos no Brasil e exterior). Nenhum cientista sério usa animais sem um fim específico e finalmente, existe uma regulamentação que é imposta ao pesquisador quando este submete seus projetos a agências financiadoras ou revistas científicas. Essa regulamentação prevê limites claros ao que se pode fazer com animais, visando minimizar o sofrimento imposto a eles. Quanto a usar animais para nossos fins, várias espécies da escala zoológica, porque não dizer todos os seres vivos, fazem parte de uma cadeia alimentar e assim fazemos nós também. Este é, talvez, o argumento mais antigo dos defensores do uso de animais, mas ainda não se conseguiu mudar tal fato. Quero ir mais longe pois não vejo motivos para parar: não se pode negar que as plantas, fungos e microorganismos das mais diversas naturezas sejam entidades vivas; assim, usando a estratégia dos antigos, a reductio ad absurdum não poderíamos usar nenhum deles para nossos fins egoístas. Talvez, então, tenhamos que nos alimentar de carcaças de animais mortos por “causas naturais” e chegaríamos imediatamente à conclusão de que os únicos animais eticamente corretos são os urubus, hienas e bactérias decompositoras.

Filósofos são treinados a expressar e defender suas idéias. Bertrand Russell é considerado por muitos o maior filósofo contemporâneo. Morreu em 1970 aos 98 anos. Em seu pequeno livro intitulado "No que acredito" (no Brasil, L\&PM Editores, 2007) Russell advogava em 1925, ano de sua publicação, que o homem tem o dever de usar seu intelecto para o seu próprio bem. Para usar suas próprias palavras:

\footnotetext{
"O respeito à natureza física é pura tolice; a natureza física deve ser estudada no intuito de se fazer com que sirva... aos propósitos humanos, ainda que, do ponto de vista ético, ela permaneça nem boa, nem má."
}

Contam seus estudiosos, que Russell foi muito criticado por esta frase. É compreensível que um homem ilustrado perca a paciência diante do dogmatismo e autoritarismo e mude o tom do discurso, pois esta frase se encontra no final do livro. Entre seus argumentos iniciais está uma frase que precisa estar em nossas mentes:

\footnotetext{
"A filosofia da natureza é uma coisa; a filosofia do valor é totalmente distinta. Confundi-las não gera senão prejuízo. O que consideramos bom, aquilo de que deveríamos gostar, não tem qualquer relação com o que é - questão esta concernente à filosofia da natureza."
}

O texto continua defendendo que dar valor a coisas não é errado e mesmo, admirar a beleza da natureza não tem significado, pois nós fazemos parte dela. Esses argumentos são intrigantes e expõem 
o quanto somos ingênuos e precipitados em nossos julgamentos. $O$ que move os críticos do uso de animais em experimentação e o que move os cientistas que usam animais, são sentimentos positivos e construtivos. No entanto os métodos usados por estes ideólogos são muitas vezes, inconcebíveis. Soube de um caso ocorrido em um dos laboratórios em que estagiei que merece ser lembrado. Um hospital psiquiátrico em Toronto, Canadá, mantém um centro de pesquisas em suas dependências. Um grupo de militantes do banimento da experimentação animal invadiu os laboratórios durante o final de semana e soltou todos os ratos e camundongos mantidos no biotério. Os animais invadiram o hospital cheio de pacientes deprimidos, maníacos, ansiosos, terrificados, drogados e etc. O resultado foi que o hospital teve que desviar verbas do atendimento e da pesquisa para um sistema de segurança mais efetivo. Nenhuma linha de pesquisa foi modificada. Estes radicais não pensaram nas conseqüências para os pacientes... só nos animais! Para falar mais a respeito de radicalismo e preconceito, já recebi pela internet, mensagens com fotografias de animais sendo torturados e submetidos a vandalismo como material de campanha contra o uso de animais em experimentação... nunca vi nada parecido em laboratórios. Simplesmente mentiras para instigar calouros incautos e fazer a fama de alguns inescrupulosos.

Para não dizermos que Russell foi um frio pensador materialista e sem sentimentos, pouco mais à frente em seu texto, ele dá destaque a uma frase:

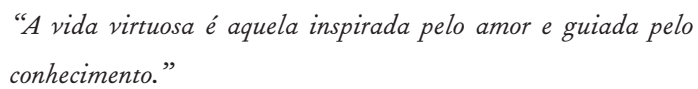

Refere-se ao papel da boa intenção e dos fins nobres a que uma atividade se dedica, como sendo o principal ingrediente a temperar a atividade humana. Continua argumentando que o conhecimento é indispensável, não bastando a boa intenção e que ele próprio prefere um bom médico a um amigo que o console, na hora da doença.

Aos que nunca leram um texto escrito por um filósofo, recomendo a leitura deste livro. Aos que acreditam que se pode dispensar o uso de animais em pesquisas, recomendo que se dediquem a buscar alternativas ao invés de combater doutrinariamente àqueles que trabalham pelo progresso do conhecimento. 